\title{
A perioperatív vérgazdálkodási program alapelvei
}

\author{
Oláh Zsolt dr. ${ }^{1}$ - Fülesdi Béla dr. ${ }^{1}$ - Gál János dr. ${ }^{2}$ \\ Matusovits Andrea dr. ${ }^{3}$. Babik Barna dr. ${ }^{4}$
}

\begin{abstract}
${ }^{1}$ Debreceni Egyetem, Általános Orvostudományi Kar, Aneszteziológiai és Intenzív Terápiás Klinika, Debrecen ${ }^{2}$ Semmelweis Egyetem, Általános Orvostudományi Kar, Aneszteziológiai és Intenzív Terápiás Klinika, Budapest ${ }^{3}$ Országos Vérellátó Szolgálat, Budapest

${ }^{4}$ Szegedi Tudományegyetem, Általános Orvostudományi Kar, Aneszteziológiai és Intenzív Terápiás Intézet,
\end{abstract} Szeged

\begin{abstract}
A perioperatív Patient Blood Management hazai adaptációja, a Nemzeti Véradó és Vérmentő Program átfogó, komplex megközelítést alkalmazó, multidiszciplináris konszenzuson alapuló és egyénre szabott klinikai gyakorlat, mely támogatja a vérkészítmények észszerú és indokolt alkalmazását, de megszünteti az irracionális transzfúziós gyakorlatot. A program gyakorlati megvalósítása három pilléren nyugszik: 1) a vérkép rendezése, lehetőleg transzfúzió nélkül; restriktív transzfúziós gyakorlat alkalmazása; 2) a vérvesztés minimalizálása; 3 ) az anaemiával szembeni tolerancia fokozása. A nagy vérzésveszéllyel járó mútétek előtt az anaemia mihamarabbi észlelése, az etiológia tisztázása és megfelelő kezelése a legfontosabb a vérkép rendezése érdekében. A vérvesztés minimalizálása a veleszületett vagy szerzett vérzékenységben szenvedő betegek kiszưrésével és megfelelő mütéti előkészítésével, az antikoaguláns, illetve thrombocytaaggregáció-gátló készítmények műtét előtti, az aktuális ajánlások szerint történő kihagyásával, szükség esetén hatásuk felfüggesztésével érhető el. Előnyben részesítendők a minimálinvazív eljárások. A műtét alatt a sebész részéról fontos az atraumatikus technika és a gondos lokális vérzéscsillapítás. Az autológ vérmentési technikák és ellenjavallat hiányában a kontrollált hypotensio szintén csökkenti az elvesztett vér mennyiségét. Perioperatív vérzés ellátása során a nemzetközi ajánlásokat tartalmazó, de a helyi viszonyokhoz adaptált kezelési protokoll alkalmazása szükséges, mely ideális esetben faktorkoncentrátum-alapú, viszkoelasztikus teszttel monitorozott, célvezérelt és egyénre szabott. A teljes perioperatív időszakban biztosítani kell az oxigén kereslet/kínálat ideális arányát, kerülve az oxigénadósság kialakulását. A homeostasis helyreállítása és fenntartása alapvető jelentőségű a haemostasisrendszer hatékony mưködéséhez és az oxigénadósság elkerüléséhez is. A Nemzeti Véradó és Vérmentő Program alkalmazása növeli a betegbiztonságot, csökkenti a betegellátás költségeit, és országos szinten elősegíti a vérkészítmény-ellátás biztosítását. Sikeres bevezetése mindannyiunk közös érdeke.
\end{abstract}

Orv Hetil. 2020; 161(37): 1554-1568.

Kulcsszavak: anaemia, masszív vérzés, masszív transzfúzió, Patient Blood Management, viszkoelasztikus véralvadási tesztek

\section{Principles of the perioperative Patient Blood Management}

The perioperative Patient Blood Management (in Hungary National Blood Donation and Blood Saving Program) is an individualized clinical practice based on a multidisciplinary consensus with a comprehensive and complex approach. It supports the rational and judicious utilization of blood products and abolishes irrational transfusion policy. Its practical implementation is based upon three pillars: 1. anemia management without transfusion, if possible; restrictive transfusion strategy; 2. minimization of blood loss; 3 . enhancement of anemia tolerance. Early detection, clarification of etiology and appropriate treatment are the most important tools for the management of preoperative anemia before surgeries with a high risk of bleeding. Minimization of blood loss can be achieved by identifying patients with congenital or acquired bleeding disorders, preparing them appropriately for surgery, discontinuing anticoagulants and antiplatelet drugs for a sufficient time in the preoperative phase of surgery and reversing their effects to comply with current guidelines. Minimal-invasive approaches are preferable. Intraoperatively, atraumatic technique and accurate topical haemostasis should be provided by surgeons. Autologous blood salvage techniques and controlled hypotension in lack of contraindications can also reduce the amount of blood loss. In cases of perioperative bleeding, protocols based on international guidelines but adapted to local circumstances must be used. Ideally, it should be managed by viscoelastic test-guided, goal-directed, individualized and factor concentrate-based algo- 
rithm. Perioperatively, an ideal oxygen demand/supply ratio must be ensured to avoid oxygen debt. Restoration and maintenance of homeostasis are essential for both the effectively functioning haemostatic system and the avoidance of oxygen deficit. Implementation of the Patient Blood Management improves patient safety, reduces the cost of medical care and facilitates the national blood product supply. Its successful introduction is our common interest.

Keyvords: anemia, massive bleeding, massive transfusion, Patient Blood Management, viscoelastic haemostatic tests

Oláh Zs, Fülesdi B, Gál J, Matusovits A, Babik B. [Principles of the perioperative Patient Blood Management]. Orv Hetil. 2020; 161(37): 1554-1568.

(Beérkezett: 2020. március 10.; elfogadva: 2020. április 20.)

\begin{abstract}
Rövidítések
APTI = aktivált parciális tromboplasztinidő; $\mathrm{CRP}=$ C-reaktív protein; $\mathrm{EPO}=$ eritropoetin; ESA = erythropoesist stimuláló készítmények; EU = Európai Unió; FFP = friss fagyasztott plazma; fl = femtoliter $\left(10^{-15}\right.$ liter $)$; Hb = hemoglobin; HTCmin = a beteg által még tolerálható legkisebb hematokritérték; $\mathrm{HTC}_{\text {preop }}=$ mútét előtti hematokrit; iCa = ionizált kalcium; INR $=($ international normalized ratio $)$ nemzetközi normalizált ráta; MAITSZK = a Magyar Aneszteziológiai és Intenzív Terápiás Társaság Szakmai Kollégiuma; $\mathrm{MCV}=$ (mean corpuscular volume) vörösvérsejtek átlagos térfogata; OVSZ = Országos Vérellátó Szolgálat; PBM = (Patient Blood Management) hazai adaptációja a Nemzeti Véradó és Vérmentő Program; $\mathrm{PCC}=$ protrombinkomplex-koncentrátum; $\mathrm{PI}=$ protrombinidó; POC $=$ (point-of-care) betegágy melletti; THR = thrombocyta; $\mathrm{TI}=$ trombinidő; TrfSAT = transzferrinszaturáció; TRIM = (transfusion-related immunomodulation) transzfúzióval kapcsolatos immunmoduláció; VV = vértérfogat; VVS = vörösvérsejt; WHO = (World Health Organization) Egészségügyi Világszervezet
\end{abstract}

A klinikai gyakorlatban az anaemia/vérvesztés kezelésekor még mindig a - veszélyektől sem mentes - transzfúzió merül fel elsővonalbeli terápiaként. Az Európai Unióban évente kb. 5 millió beteg részesül transzfúzióban, összesen 25 millió egység labilis vérkészítmény felhasználásával, annak ellenére, hogy számos, evidenciákon alapuló terápiás lehetőség áll rendelkezésre az anaemia és a vérvesztés megelőzésére, rendezésére és a transzfúziók számának, mennyiségének csökkentésére [1]. A transzfúziós igényeknek és a donorok számának alakulása, illetve aránytalansága előrevetíti, hogy 2050-re a helyzet világszerte - így Európában is - kritikussá válhat.

A WHO 2011-ben szervezett globális fórumot a vérkészítmény-ellátás biztosítását és a jobb terápiás kimenetelt célzó alapelvek meghatározása érdekében, amelyen elfogadták a vérfelhasználás racionalizálását és a szükségtelen transzfúziós gyakorlat korlátozását célzó, multidiszciplináris konszenzuson alapuló komplex program bevezetésének szükségességét, mely a nemzetközi irodalomban a kifejező Patient Blood Management (PBM) néven vált általánosan elfogadottá $[2,3]$. A fenti kifejezést és rövidítést így magunk is használjuk a továbbiakban. A PBM tehát egy evidenciákon alapuló, multidisz- ciplináris, egyénre szabott, betegközpontú koncepció, amely az anaemia megelőzésével és kezelésével, a vérveszteség és a transzfúziók számának csökkentésével a jobb kimenetelt és a betegek biztonságát szolgálja [4]. Magyar nyelvű, hivatalos megfelelőjeként a Nemzeti Véradó és Vérmentő Program elnevezést javasoljuk. 2019-ben a Magyar Aneszteziológiai és Intenzív Terápiás Társaság szervezésében a közép-európai régió szakértői Budapesten találkoztak, hogy megosszák egymással a PBM bevezetésével kapcsolatos szervezési és szakmai tapasztalataikat, illetve megvitassák ezzel kapcsolatos kérdéseiket [5]. A témában kiváló magyar nyelvű összefoglalók is megjelentek a közelmúltban $[6,7]$. Az alábbiakban vázolt koncepciót - a Nemzeti Véradó és Vérmentő Programot - a PBM magyar viszonyokhoz adaptált szakmai ajánlásának, az irányelvek bemutatkozó vitaanyagának szánjuk.

\section{Az anaemia, a vérvesztés és a transzfúzió triásza: a kedvezőtlen kimenetel független kockázati tényezői}

\section{Anaemia}

Anaemia nagyon gyakran fordul elő a perioperatív időszakban, illetve súlyos betegségekhez társulva. Elektív sebészeti beavatkozásra váró betegek körében a különböző felmérések 5-75\%-ban észlelték a jelenlétét, a legnagyobb arányban az idősebb betegeket érinti [8]. Az anaemia a kedvezőtlen mútéti kimenetel jelentős és független kockázati tényezője: megnő a kórházi tartózkodási idő, valamint az összesített morbiditási és mortalitási ráta is $[8,9]$.

\section{Perioperatín vérvesztés}

A perioperatív vérvesztés szintén a kedvezőtlen kimenetel független prediktora [9]. Az akut és/vagy jelentős vérzés nem anaemiás betegeknél is azonnali, súlyos következményekkel járhat: vérzéses sokk és szekunder coagulopathia révén további szövődmények, szervkárosodás és életet veszélyeztető állapot alakulhat ki $[10,11]$. A súlyos, életveszélyes szövődmények gyakran gyógyítható 
alapbetegségben szenvedő pácienseket érintenek, de fiatal, addig egészséges egyéneket is fenyegethet trauma vagy szülés kapcsán. A szívsebészeti betegellátásban a masszív vérzések előfordulása 2-24\% [12-15]. Súlyos traumát szenvedett betegek 15\%-ában fordul elő jelentős vérzés, mely a poszttraumás halálozás 40\%-áért tehetó felelőssé, és ezáltal a sérült betegek potenciálisan megelőzhető haláleseteinek vezető okává lépett elő [16]. A szülészeti masszív vérzések az anyai halálozás 25-30\%ához járulnak hozzá közvetlenül [17, 18].

\section{Transzfúzió}

A vörösvérsejt (VVS)-koncentrátum alkalmazása hemodinamikailag instabil állapotú, vérző, anaemiás betegeknél életmentő. Kevés evidenciával rendelkezünk azonban arról, hogy a VVS-transzfúzió előnyös lenne hemodinamikailag stabil állapotú és/vagy krónikus anaemiában szenvedő betegek esetén. A VVS-transzfúziók egy jelentős része mégis ebben a betegcsoportban történik [19]. A transzfúzió korrigált laboratóriumi eredményekhez vezet ugyan, de nem orvosolja az anaemia okait, és nem szünteti meg a vérzést, illetve a transzfundált VVS-koncentrátum oxigénszállító kapacitása is némileg korlátozott [20]. A transzfúzió okozta immunmoduláció (TRIM: transfusion-related immunomodulation) és a posztoperatív fertőzések, daganatos megbetegedések előfordulása közötti összefüggés napjainkban is klinikai és tudományos kutatások tárgyát képezi. Randomizált, kontrollált vizsgálatok metaanalízise igazolta, hogy a liberális transzfúziós küszöbértékek alkalmazása növeli a kórházi tartózkodás alatt szerzett infekciók gyakoriságát [21, 22]. A vérkészítmények használatával kapcsolatban számos korai és késői transzfúziós reakció és szövődmény került leírásra. A transzfúzióval összefüggésbe hozható halálozás kétharmadáért a transzfúzióval kapcsolatos akut tüdőkárosodás, keringés-túlterhelés és a fentebb említett immunmoduláció révén kialakuló, kórházban szerzett infekciók tehetők felelőssé. Az allogén vérkészítmények indokolatlan alkalmazása tehát független, dózisfüggő és additív morbiditási és mortalitási kockázati tényező [22-24].

\section{A Nemzeti Véradó és Vérmentő Program bevezetésének szervezési kérdései}

A PBM sikeres bevezetése az előbbiekben részletezett, a kedvezőtlen kimenetel valószínúségét fokozó triász kialakulásának megelőzése és kezelése révén csökkenti a mortalitást, a morbiditást, a kórházi tartózkodás időtartamát és költségeit [25-29].

A rendelkezésre álló szakmai evidenciák és az EU 2017-ben megjelentetett PBM-irányelvei [30] alapján az Egészségügyi Szakmai Kollégium és az Országos Vérellátó Szolgálat kezdeményezni kívánja a PBM bevezetését Magyarországon a következő célokkal:
- a kórlefolyás kimenetelének javítása a szükségtelen transzfúziók elkerülésével és így a transzfúzióhoz köthető szövődmények csökkentésével;

- mindenkor elegendő vérkészítmény biztosítása a transzfúziót ténylegesen igénylő betegek számára;

- a kórházi transzfúzióval összefüggésbe hozható költségek optimalizálása/csökkentése az allogén és stabil vérkészítmények alkalmazásának egységes szemléletével. A PBM bevezetése az egészségügyi ellátórendszer számos szereplőjét érinti:

- szakterületek: aneszteziológia és intenzív terápia, általános sebészet, szívsebészet, érsebészet, transzplantációs sebészet, traumatológia, sürgősségi ellátás, gasztroenterológia, szülészet-nőgyógyászat, hematológia, onkológia;

- vérellátó szolgálatok;

- transzfúzióért felelős orvosok és szervezeti egységek;

- kórházak vezetősége/gazdasági igazgatóság/fógyógyszerész;

- és az egészségügyi kormányzati szervek egyaránt jelentős mértékben tudnak hozzájárulni a program elterjedéséhez, bevezetéséhez.

A PBM sikeres bevezetéséhez és elveinek a gyakorlatba történó átültetéséhez elengedhetetlen a PBM-hez kapcsolódó oktatási programok szervezése, a PBM multidiszciplináris, proaktív alkalmazása és hatékonyságának monitorozása.

A PBM-program bevezetéséhez az alábbi feltételek biztosítása szükséges:

- multidiszciplináris konszenzuson alapuló nemzeti PBM-ajánlás létrehozása;

- kórházi PBM-program bevezetése;

- kórházi PBM-munkacsoportok felállítása (aneszteziológus, sebész, traumatológus, szülész-nőgyógyász, belgyógyász/hematológus, transzfuziológus, gyógyszerész és egyéb társszakmák képviselői önkéntes alapon), valamint a Vérellátó Szolgálat képviselői, egy koordinátor megnevezésével;

- a kórházi PBM-munkacsoport feladatai:

o széles körű tájékoztatás a PBM-program létrejöttéról, annak fontosságáról (szórólapok, média, online anyagok az orvostársadalom és a lakosság számára is),

o standard operációs protokollok kidolgozása és bevezetése,

o PBM-képzések szervezése a programban érintett résztvevők számára,

o nyomon követési kritériumok meghatározása és monitorozása,

o kapcsolattartás a kórházi osztályokkal, a kórház vezetőségével.

A PBM bevezetése által elért változások monitorozása a következő adatok követésével lehetséges:

- preoperatív időszak:

o a mütétre kerülő, nem kivizsgált és gyógyszeresen nem kezelt, illetve megfelelően kivizsgált és kezelt anaemiás betegek aránya, 
o az (elektív) mütét előtt transzfúzióban részesülő betegek aránya, az alkalmazott transzfúziók menynyisége;

- intrahospitális/intraoperatív időszak:

o a 'cell saver', faktorkoncentrátumok és transzfúzió alkalmazásának, illetve felhasznált mennyiségének aránya, elsősorban a major és masszív vérzéssel járó események során,

o transzfúzió előtti átlagos hemoglobinszint, thrombocytaszám,

o az indokolatlanul alkalmazott transzfúzió mennyisége (az ajánlástól eltérően adott transzfúzió),

o a lejárati időn belül fel nem használt, kidobott vérkészítmények mennyisége;
- posztoperatív időszak - klinikai kimenetel/eredmények, szövődmények értékelése:

o a transzfúziós reakciók és szövődmények száma,

o a kórházi, azon belül intenzív osztályos tartózkodás időtartama (napok),

o morbiditási adatok: elsősorban infekciók (szepszis, pneumonia stb.), akut veseelégtelenség, akut myocardialis infarctus, akut ischaemiás stroke,

o kórházi újrafelvétel,

o reoperációs ráta,

o anaemia az elbocsátáskor,

o mortalitás:

- a kórházi tartózkodás idején,

- 30 napon és 1 éven belül;

1. táblázat |A Nemzeti Véradó és Vérmentő Program összefoglalása

\begin{tabular}{|c|c|c|c|}
\hline & Preoperatív időszak & Intraoperatív időszak & Posztoperatív időszak \\
\hline \multirow{2}{*}{$\begin{array}{l}\text { A vérkép rendezése, } \\
\text { lehetőség szerint } \\
\text { transzfúzió nélkül }\end{array}$} & \multicolumn{3}{|c|}{$\begin{array}{l}\text { Restriktív transzfúziós gyakorlat: az allogén vérkészítmények megfontolt használata (a transzfúziós trigger gondos, } \\
\text { individuális meghatározása; tünetmentes és krónikus vagy hiányanaemiát ne kezeljünk transzfúzióval) }\end{array}$} \\
\hline & $\begin{array}{l}\text { Az anaemia } \\
\text { - korai felismerése } \\
\text { - etiológiájának tisztázása } \\
\text { - oki és gyógyszeres kezelése } \\
\text { (vaspótlás, EPO, } \mathrm{B}_{12} \text {-vitamin, } \\
\text { folsav stb.) } \\
\text { Elektív mútét tervezett idópontjának } \\
\text { meghatározása a vérkép ismeretében } \\
\text { (is) történjen }\end{array}$ & $\begin{array}{l}\text { - Elsősorban a vérvesztés csökkentése } \\
\text { (lásd a vérvesztés minimalizálása } \\
\text { - intraoperatív időszak) } \\
\text { - Gondos preoperatív előkészítés } \\
\text { (lásd a preoperatív időszak } \\
\text { oszlopban) révén érhető el }\end{array}$ & $\begin{array}{l}\text { Az anaemia } \\
\text { - etiológiájának tisztázása } \\
\text { - oki és gyógyszeres kezelése } \\
\text { (vaspótlás, EPO), megfelelő } \\
\text { táplálás, vitaminok és nyomelemek } \\
\text { bevitele } \\
\text { Infekciók megelőzése és kezelése }\end{array}$ \\
\hline \multirow[t]{2}{*}{$\begin{array}{l}\text { A vérvesztés } \\
\text { minimalizálása }\end{array}$} & \multicolumn{3}{|c|}{$\begin{array}{l}\text { - A iatrogén vérvesztés minimalizálása: a vérvételek számának racionalizálása, kis mennyiségű frakciók levétele } \\
\text { - A homeostasis fenntartása: normothermia, a sav-bázis háztartás egyensúlyának biztosítása, az iCa-szint fenntartása }\end{array}$} \\
\hline & $\begin{array}{l}\text { - A haemostasis veleszületett és/vagy } \\
\text { szerzett zavarainak időben történő } \\
\text { felismerése (kérdőív, szükség esetén } \\
\text { laborvizsgálat, szakkonzíliumok) } \\
\text { - Az ok ismeretében a haemostasis- } \\
\text { zavar rendezése } \\
\text { - Indokolt esetben a haemostasisra } \\
\text { ható gyógyszerek időben történő } \\
\text { kihagyása vagy hatásuk felfüggesz- } \\
\text { tése (faktorkoncentrátumok célzott } \\
\text { használata preferált az allogén } \\
\text { vérkészítmények alkalmazásával } \\
\text { szemben) }\end{array}$ & $\begin{array}{l}\text { - Atraumatikus sebészeti technika } \\
\text { - Minimálinvazív beavatkozások } \\
\text { preferálása } \\
\text { - Gondos sebészi vérzéscsillapítás } \\
\text { - Lokális hemosztriptikumok szükség } \\
\text { szerinti alkalmazása } \\
\text { - Autológ vérmentő technika } \\
\text { alkalmazása (cell saver), autológ vér } \\
\text { (re)transzfúziója } \\
\text { - Kontrollált hypotensio megfontolt } \\
\text { alkalmazása } \\
\text { - Vérzés esetén VE POC-teszttel } \\
\text { monitorozott célzott kezelés, } \\
\text { faktorkoncentrátumok preferálása, } \\
\text { a szekunder coagulopathia } \\
\text { megelőzése, helyi protokoll } \\
\text { alkalmazása } \\
\text { - Regionális anesztézia preferálása }\end{array}$ & $\begin{array}{l}\text { - A posztoperatív vérzés követése, } \\
\text { kezelése } \\
\text { - A szekunder coagulopathia } \\
\text { megelözése, kezelése (faktorkon- } \\
\text { centrátumok preferálása) } \\
\text { - Autológ vérmentési eljárások } \\
\text { - A posztoperatív vérzés és anaemia } \\
\text { kialakulásának megelőzése } \\
\text { (stresszulcus-profilaxis, egyénre } \\
\text { szabott haemostasis/antikoaguláció } \\
\text { biztosítása, anaemiát fokozó } \\
\text { gyógyszerhatások felismerése és } \\
\text { lehetőség szerinti megszüntetése) }\end{array}$ \\
\hline
\end{tabular}

Az anaemiával - $\mathrm{Az} \mathrm{O}_{2}$ kereslet/kínálat ideális arányának biztosítása, az $\mathrm{O}_{2}$-adósság elkerülése szembeni tolerancia - A homeostasis fenntartása

fokozása

- A fiziológiás tartalékok és rizikótényezők felmérése, rendezése, a társbetegségek megfelelő kezelése

- A várható és tolerálható vérvesztés összevetése

- Individualizált kezelési terv előzetes készítése, majd alkalmazása, rendszeres revideálása
- $\mathrm{Az} \mathrm{O}_{2}$-felhasználás minimalizálása: narkózis mélysége, fájdalomcsillapítás, szükség szerint izomrelaxáció stb.

- Megfelelő $\mathrm{O}_{2}$-kínálat biztosítása: normovolaemia, $\mathrm{O}_{2}$, inotrop szerek stb.
- $\mathrm{Az} \mathrm{O}_{2}$-felhasználás minimalizálása: légzéstámogatás, lázcsillapítás, fájdalomcsillapítás, szedáció stb.

- Megfelelő $\mathrm{O}_{2}$-kínálat biztosítása

$\mathrm{EPO}=$ eritropoetin; $\mathrm{iCa}=$ ionizált kalcium; VE POC-teszt $=$ viszkoelasztikus, betegágy melletti teszt 
- rendszeres külső és belső audit a bevezetést követően: az adatok tükrében a rendszerszintú hibák felfedése, ajánlások azok megoldására és a szükséges további változtatásokra.

\section{A Nemzeti Véradó és Vérmentő Program gyakorlati megvalósítása}

A PBM gyakorlati kivitelezése három fó pilléren nyugszik. A teendők didaktikus áttekintése érdekében a perioperatív időszakot mútét előtti, alatti és utáni periódusokra érdemes osztani (1. táblázat) [29].

\section{Elsö pillér: a vérkép rendezése}

\section{Az anaemia és a vashiány idöben történó felismerése}

A WHO meghatározása alapján anaemiának minősül, ha a hemoglobin ( $\mathrm{Hb}$ ) értéke < $130 \mathrm{~g} / 1$ férfiaknál, < $120 \mathrm{~g} / \mathrm{l}$ nem várandós és < $110 \mathrm{~g} / \mathrm{l}$ várandós nőknél. Az anaemia globális egészségügyi probléma, melyet az esetek jelentős részében vashiány okoz, preoperatív rendezése alapvető szakmai elvárás. A közepesen nagy vagy nagy vérzésveszéllyel járó és így a transzfúzió lehetőségét relatíve nagy valószínüséggel magában hordozó beavatkozások előtt elérendő Hb-célérték - nemtől függetlenül - >130 $\mathrm{g} / \mathrm{l}$, a vasraktárak telítettségét tükröző ferritincélérték pedig > $100 \mu \mathrm{g} / \mathrm{l}$. Elektív mútétre váró anaemiás beteg mútéti felkészítése során az anaemia csökkentésére és/ vagy megszüntetésére az aktuálisan érvényes Európai Aneszteziológiai Társaság ajánlásának alkalmazása javasolt [31]:

- Magas vérzési kockázattal bíró beteg/mútét esetén az anaemia igazolása és kivizsgálása a beavatkozás előtt 3-8 héttel történjen meg ( $1 \mathrm{C}$ ajánlás): ezekben az esetekben már a mütét indikációjának felállításakor javasolt a vérkép, ferritin, transzferrinszaturáció (TrfSAT), CRP és vesefunkció vizsgálata a sebészeti ambulancián/osztályon.

- Anaemia esetén a kiváltó okok tisztázása szükséges (vashiány, veseelégtelenség, idült gyulladás, egyéb) (1C).

- A vashiányos anaemia azonnali kezelése indokolt: vaspótló terápia alkalmazása (1B) per os vagy intravénás (iv.) módon lehetséges, de a perioperatív időszakban általában az iv. vaskészítmény részesítendő előnyben (1C).

- Ha az anaemia a részletes kivizsgálás és kezelés ellenére terápiarezisztensnek bizonyul, ellenjavallat hiányában az erythropoesist stimuláló ágensek (ESA) alkalmazása megfontolandó (1B).

- Szükség esetén iv. vaskészítmény és eritropoetin (EPO) együttes alkalmazása ajánlott, restriktív transzfúziós szemlélet mellett (1C).
Az anaemia megállapításához a teljes vérkép szolgáltat információt, a vashiány megállapításához és kezeléséhez a szérumferritin, -vas, -transzferrin, -TrfSAT és -CRP meghatározása szükséges (1. ábra):

- Szérumferritin<100 g/l: a vastartalékok kimerülésére $(<30 \mu \mathrm{g} / \mathrm{l})$, illetve a vasraktárak elégtelen telítettségére $(<100 \mu \mathrm{g} / \mathrm{l})$ utal, vaskészítmény alkalmazása indokolt.

- Szérumferritin $\geq 100 \mu g / 1$ és -TrfSAT>20\%: az anaemia nem vashiányos eredetére utal, vaskészítmény alkalmazása nem indokolt - az anaemia etiológiája tisztázandó és annak megfelelően kezelendő.

- Szérumferritin 30-100 $\mu \mathrm{g} / 1$ és -TrfSAT<20\%: vashiányra \pm idült gyulladásos kórképre $(\mathrm{CRP}>5-10 \mathrm{mg} / \mathrm{l})$ utal. Az alapbetegség kezelése mellett iv. vaspótlás szükséges, válogatott esetekben megfontolást/konzultációt követően EPO alkalmazása megfontolható.

- Szérumferritin $\geq 100 \mu \mathrm{g} / 1$ és -TrfSAT<20\%: funkcionális vashiányra vagy idült gyulladásos kórképre (CRP>5-10 mg/l) utalhat, a vasfelhasználás zavara mellett a relatív vagy abszolút vashiány nem zárható ki biztonsággal. Mivel a ferritin akutfázis-fehérjeként viselkedik, diagnosztikus értéke gyulladásos folyamat esetén nem megbízható. Ilyenkor a reticulocyták alacsony Hb-tartalma ( $<28 \mathrm{pg})$, a hypochrom VVS-ek emelkedett aránya ( $>5 \%)$ vagy a ferritinindex (szérum-transzferrinreceptor/log ferritin) >2 értéke segíthet a vashiány megállapításában és a vaspótló kezelés indikációjának felállításában. Az anaemiát kiváltó alapbetegség kezelése mellett megfontolást/konzultációt követően EPO és/vagy iv. vaspótlás, illetve a már alkalmazott EPO adagjának revideálása javasolható.

- Anaemia hiányában a VVS-ek mérete (mean corpuscular volume, MCV) és a ferritinszint segíthet a latens vashiány, illetve a nem kellően telített vasraktárak fel-

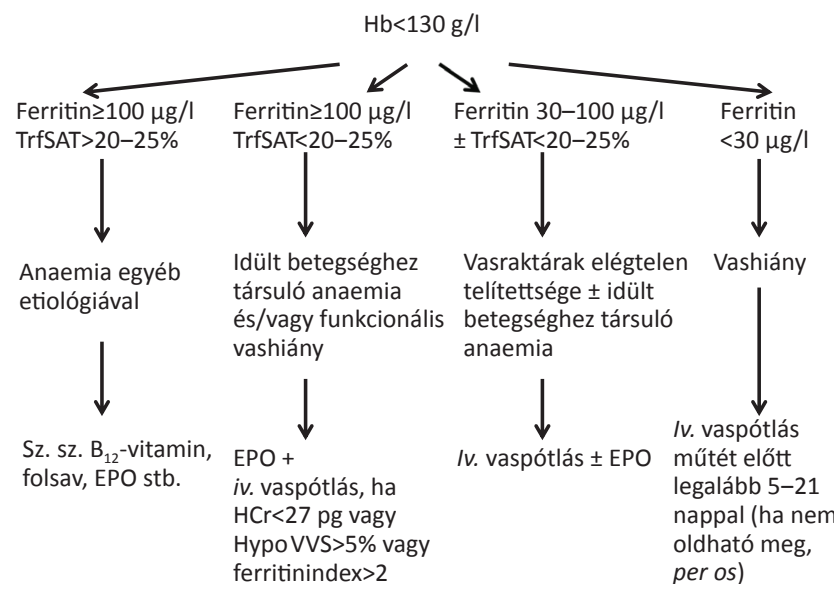

1. ábra $\quad$ Az anaemia preoperatív kivizsgálásának és kezelésének egyszerúsített, vázlatos összefoglalása

$\mathrm{EPO}=$ eritropoetin $\mathrm{Hb}=$ hemoglobin $; \mathrm{HCr}=$ a reticulocyta hemoglobintartalma; Hypo VVS = a hypochrom vörösvérsejtek aránya; $i v .=$ intravénás; sz. sz. = szükség szerint; $\operatorname{TrfSAT}=$ transzferrinszaturáció 
fedésében: microcytás vérképzés $(\mathrm{MCV}<80$ fl) esetén is érdemes a vasanyagcsere vizsgálatát elvégezni. Vashiány esetén az okot keresni és kezelni kell, illetve vaspótlást kezdeni, hogy elkerüljük az anaemia kialakulását a perioperatív időszakban, és optimalizáljuk a rendelkezésre álló vasraktárak telítettségét (cél: ferritin $\geq 100 \mu \mathrm{g} / \mathrm{l})$, különösen a nagy vérvesztés veszélyével járó beavatkozások előtt.

\section{Az anaemia és a vashiány preoperatín kezelése}

\section{Vaspótlás}

A vashiányos anaemia kezelésére a preoperatív időszakban az iv. vas alkalmazása preferált, mert az orális készítmények felszívódása lassú, illetve az alapbetegségtől függően zavart lehet, és még jól együttmúködő betegeknél is több hónapot igényelhet a vérkép rendezése. Amenynyiben az $i v$. vaspótlás nem vagy csak részben oldható meg, a per os adagolás elkezdése (is) szükséges. Minden esetben figyelni kell a megengedett maximális mennyiségü, de még biztonságosan alkalmazható vas bevitelére.

Terápiás ajánlás a preoperatív szakban:

- A vashiány diagnózisát követően azonnal vaspótlást kell kezdeni, lehetőleg iv. adagolással.

- Per os készítmény adható, ha a mútétig elegendő idő (legalább 6-8 hét) áll rendelkezésre. Célszerü napi 40-60 mg vagy másnaponta 80-100 mg elemi vas bevitele: ez a megközelítés maximalizálja a felszívódó vas arányát, és csökkenti a gastrointestinalis mellékhatások gyakoriságát.

- Abszolút vagy funkcionális vashiány, a per os vaskészítményekkel szembeni intolerancia, hatástalanság esetén, illetve ha a mütétig kevés idő áll rendelkezésre (<6 hét), iv. vaskészítmény adagolása javasolt. Iv. vas adagolására lehetőség szerint legalább 5-21 nappal a sebészeti beavatkozás előtt kerüljön sor, sürgős esetben alkalmazni lehet a beavatkozás elötti napig is.

- A dózis és az adagolás tekintetében utalunk az egyes iv. vaskészítményekkel kapcsolatos hivatalos előírások-

2. táblázat |A Ganzoni-képletből számított egyszerúsített táblázat az iv. vaskészítmény adagolásához, mely figyelembe veszi a beteg testsúlyát és a hemoglobin értékét

\begin{tabular}{lccc}
\hline \multirow{2}{*}{$\begin{array}{l}\text { Hemoglobin } \\
\text { g/l })\end{array}$} & \multicolumn{3}{c}{ A beteg testsúlya (kg) } \\
\cline { 2 - 4 } & \multicolumn{3}{c}{$\begin{array}{c}\text { A hiányzó, így a mútétig pótlandó vas } \\
\text { összmennyiségének }(\mathrm{mg}) \text { becsült értéke }\end{array}$} \\
\cline { 2 - 4 } & $900-1400$ & $1200-1700$ & $1400-2000$ \\
\hline $70-80$ & $800-1200$ & $1050-1500$ & $1250-1700$ \\
$80-90$ & $750-1100$ & $900-1250$ & $1050-1500$ \\
$90-100$ & $650-950$ & $750-1100$ & $850-1250$ \\
$100-110$ & $600-800$ & $650-900$ & $700-1000$ \\
$110-120$ & $500-650$ & $500-700$ & $500-750$ \\
$120-130$ & &
\end{tabular}

ra. A vashiány mértékének és az összesített vasszükségletnek a megállapításában segítséget nyújt a Ganzoni-képlet, illetve az egyenlet alapján készített egyszerüsített táblázat (2. táblázat) [32].

Ganzoni-képlet:

Teljes vashiány, $\mathrm{mg}=$ testsúly, $\mathrm{kg} \times($ cél- $\mathrm{Hb}, \mathrm{g} / \mathrm{dl}-$ aktuális $\mathrm{Hb}, \mathrm{g} / \mathrm{dl}) \times 2,4$ + vasraktár, mg.

A vasraktár $\geq 35 \mathrm{~kg} 500$ mg-nak, <35 kg 15 mg/kgnak vehető.

- A vas pótlása aktív infekció esetén kontraindikált.

- Amennyiben az iv. vaspótlás nem kivitelezhető, vagy csak részleges, per os szupplementáció megkísérelhető.

\section{Erythropoesist stimuláló készitmények}

$\mathrm{Az}$ anaemia speciális formáinak kezelésére (veseelégtelenséghez, kemoterápiával kezelt daganatos betegségekhez, egyéb idült betegséghez társuló anaemia stb.) jó hatékonysággal alkalmazhatók erythropoesist stimuláló készítmények. Alapfeltétel a vérképzéshez szükséges építőelemek szükség szerinti biztosítása (vas, folsav, $\mathrm{B}_{12}$-vitamin stb.) az ESA indítása előtt vagy azzal párhuzamosan.

Magyarországon alkalmazásuk a következő indikációkban elfogadott és támogatott:

- tüneteket okozó anaemia kezelése krónikus veseelégtelenség esetén;

- tüneteket okozó anaemia kezelése kemoterápiában részesülő daganatos betegeknél, illetve a myelodysplasiás szindróma egyes eseteiben;

- a VVS-volumen növelése mérsékelt anaemiában, normális vasháztartásra jellemző paraméterek mellett, autológ VVS-donáció előkészítésére;

- a VVS-transzfúziós igény csökkentése mérsékelt anaemia esetén major ortopédiai műtét előkészítésekor.

A krónikus veseelégtelenségben szenvedő betegek tartós ESA-kezelését nefrológusok, a daganatos betegekét hematológus és/vagy onkológus irányítja. Az utóbbi években azonban a perioperatív időszakban, a PBM részeként átmenetileg alkalmazott EPO-kezelés is egyre szélesebb körben terjed.

Az Európai Unióban az elektív, nagy ortopédiai mútétek perioperatív időszakában a rekombinált humán EPOkészítmények 100-130 g/l Hb-érték esetén alkalmazhatók a következő adagolási javaslattal: $300 \mathrm{NE} / \mathrm{kg} /$ nap a -10-+4. nap közötti időszakban vagy $600 \mathrm{NE} / \mathrm{kg}$ a -21., -14 ., -7 . és 0 . napon (a 0 . nap a mütét napjának felel meg). Az USA-ban nemcsak ortopédiai, hanem egyéb elektív, nem szív- és érsebészeti mútétek esetében is törzskönyvezett az EPO perioperatív alkalmazása [33, 34].

A közeljövőben indokoltnak tûnik az EPO-készítmények felírhatóságának jogosultsági és indikációs körét a kormányzati egészségügyi szervekkel együttmúködve áttekinteni a perioperatív időszakban történő szélesebb körü alkalmazásuk érdekében. 


\section{A mütét idözitése az optimális hematológiai viszonyok függvényében}

Az anaemia elektív mútétek esetén relatív kontraindikációt jelent, és a beavatkozás előtt annak oki és gyógyszeres kezelése szükséges. Transzfúzió alkalmazása csak ultimum refugiumként jön szóba. Az elektív mútét időpontját ezért úgy kell megállapítani, hogy elegendő idő álljon rendelkezésre a vérkép és szükség esetén a haemostasis zavarainak (lásd később) rendezéséhez. A PBM-program elemeit elsősorban az $500 \mathrm{ml}$-nél nagyobb vérveszteség kockázata esetén kell alkalmazni, így a tervezett sebészeti beavatkozás vérzési kockázatának elemzését minden esetben el kell végezni [29]. Magas vérzési kockázattal járó elektív mútétek előtt az anaemia és a haemostasis zavarainak mihamarabbi felismerése, majd hatékony rendezése kulcsfontosságú az időveszteség elkerülése érdekében. Mindez az aneszteziológiai ambulanciákon vagy - a leghatékonyabban - dedikált perioperatív anaemia/ haemostasis ambulancia kialakításával oldható meg. Sürgősségi mútétek esetén a racionális transzfúzió elve követendő a transzfúziós trigger figyelembevételével és a restriktív transzfúziós gyakorlat alkalmazásával.

\section{Perioperatio anaemia/haemostasis ambulancia müködtetése}

A mútét előtt észlelt anaemia és/vagy haemostasiszavar kivizsgálása és kezelése a leghatékonyabban az erre a célra kialakított perioperatív anaemia/haemostasis ambulanci- án lehetséges, mely - betegszámtól függően - legalább heti 2-4 óra rendelési idővel és a perioperatív hematológiában/haemostasisban járatos aneszteziológus és/vagy hematológus vezetésével múködik (2/a ábra).

A közepesen nagy/nagy vérzésveszéllyel járó mútétek/betegek esetében célszerú a vérkép vizsgálatát és a potenciálisan vérzékenységben szenvedő betegek kiszürését (1. melléklet) a mútéti indikáció felállításakor azonnal - még a sebészeti osztályon/ambulancián - elvégezni. Amennyiben anaemia, micro-, esetleg macrocytás vérképzés (MCV alapján), a vasraktárak elégtelen telítettsége igazolódik, vagy vérzékenység gyanúja merül fel, a beteget aneszteziológiai ambulanciára vagy ideális esetben perioperatív anaemia/haemostasis szakrendelésre kell irányítani. Amennyiben általános aneszteziológiai ambulanciára kerül a beteg, el kell végezni a vérzékenységirányú anamnézis felvételét is (a leghatékonyabban kérdőívek használatával), majd a beteget indokolt esetben a helyi protokoll szerint illetékes járóbetegszakrendelés(ek)re kell utalni a további szükséges vizsgálatok elvégzése és az anaemia/haemostasiszavar kezelésének mihamarabbi elkezdése, annak gyakorlati kivitelezése céljából $(2 / b$ ábra $)$. Amennyiben perioperatív anaemia/haemostasis szakrendelés múködik, az anaemia és a haemostasiszavar kivizsgálását és kezelését ennek keretében kell elvégezni és összefogni aneszteziológus és/ vagy hematológus által. A mútét előtt legalább l-2 héttel ismételt vizsgálat szükséges az aneszteziológiai ambulancián az elvégzett vizsgálatok és kezelés áttekintése, esetleges további vizsgálatok és kezelés indikálása céljából.

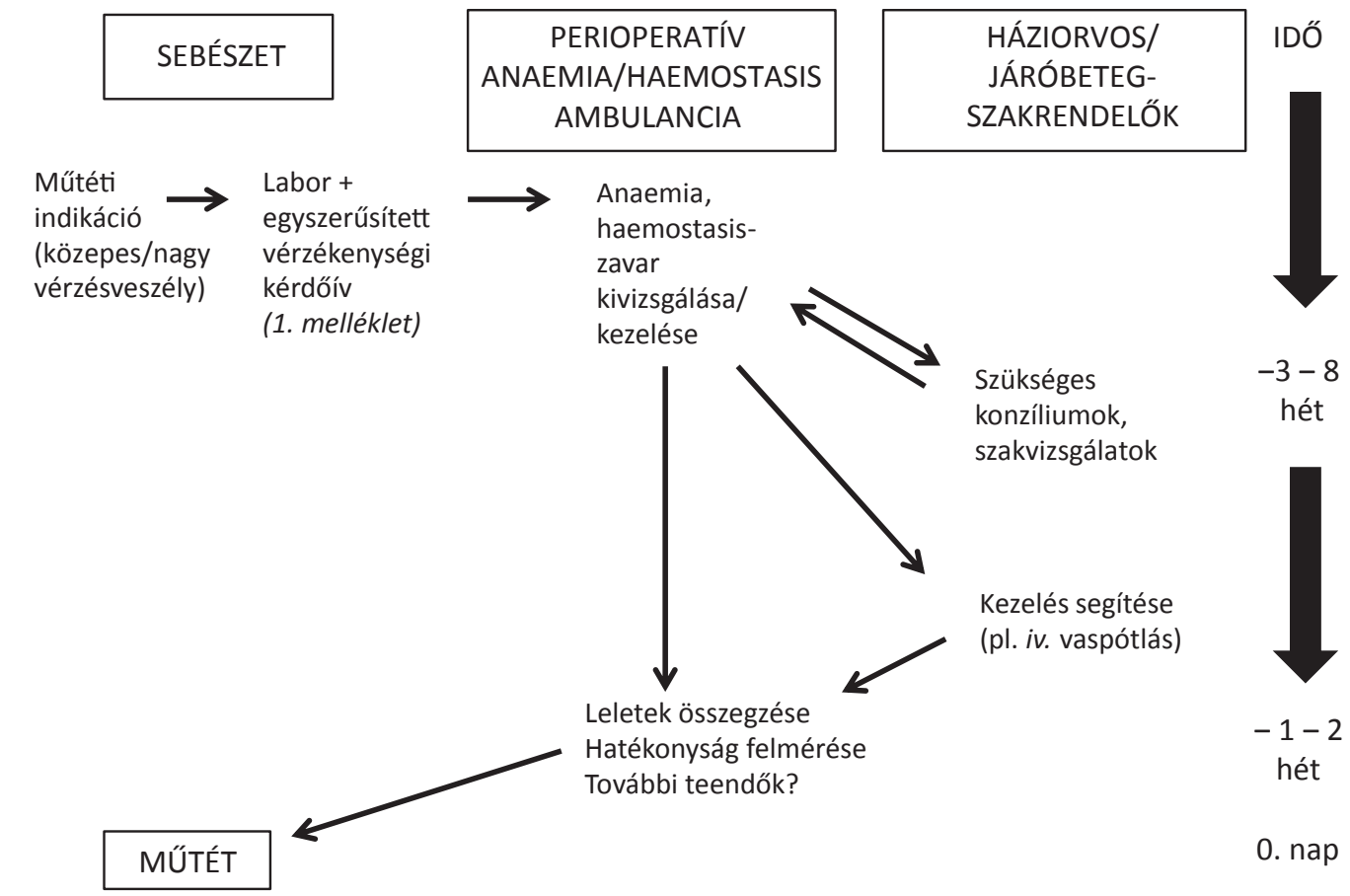

2/a ábra Az anaemia preoperatív kivizsgálásának és kezelésének szervezése, a feladatok megosztása, ha perioperatív anaemia/haemostasis ambulancia rendelkezésre áll

iv. = intravénás 
1. melléklet | Egyszerúsített kérdéssor potenciálisan vérzékeny betegek kiszúrésére

Fogászati beavatkozás után szorult-e a beteg vérzés miatt ismételt ellátásra?

Bármilyen invazív beavatkozás után szorult-e a beteg vérzés miatt ismételt ellátásra?

Korábbi sérülés, trauma, beavatkozás kapcsán tapasztalt-e a beteg a sérülés mértékéhez képest egyértelmúen aránytalan fokú vérzést?

Spontán vérzéseket tapasztalt-e már a beteg? (Egyértelmű ok, külső behatás nélkül jelentkező suffusiók, haematomák a bőrön, izomban, ízületi bevérzés, nyálkahártyavérzések: orrvérzés, ínyvérzés, haematuria, nagyon elhúzódó, nagyon bőséges menstruáció stb.)

A vérrokonságban van-e vérzékeny vagy arra gyanús beteg?

Értékelés: Bármely kérdésre adott IGEN válasz esetén részletes vérzékenységi kérdöí kitöltése és indokolt esetben további kivizsgálás javasolt (lásd a szöveges részben)

\section{Második pillér: a vérvesztés minimalizálása}

\section{A haemostasis funkciózavarainak preoperatio észlelése és kezelése}

Mütét előtt a haemostasisrendszer elégtelen múködéséhez vezető, veleszületett vagy szerzett állapotok és betegségek felismerése elengedhetetlen.

Irányelvek a potenciálisan vérzékeny betegek kiszúrésére és kezelésére [31, 35]:

- Sebészeti és invazív beavatkozások előtt fontos a haemostasis rendszerét érintő betegségek, illetve az annak múködését befolyásoló tényezők feltárása az anamnézis részletes felvételével, melyhez komoly segítséget nyújtanak a standardizált kérdőivek. Az anamnézis tisztázása során ki kell térni az egyéni és a családi anamnézisre, valamint a gyógyszerhasználatra is $(\mathrm{IC})$.

- Az anamnézis, a standardizált haemostasis-kérdőívek (2. melléklet) [36] használata elönyösebb a hagyományos laboratóriumi vizsgálatok (APTI, PI/INR és thrombocyta) rutinszerü mérésével szemben elektív mútéti beavatkozások esetében (1C). A haemostasis alvadási tesztek rutinszerú, minden betegre kiterjesztett vizsgálata nem indokolt, de bizonyos betegcsoportokban és egyes mütéti beavatkozások előtt szük-

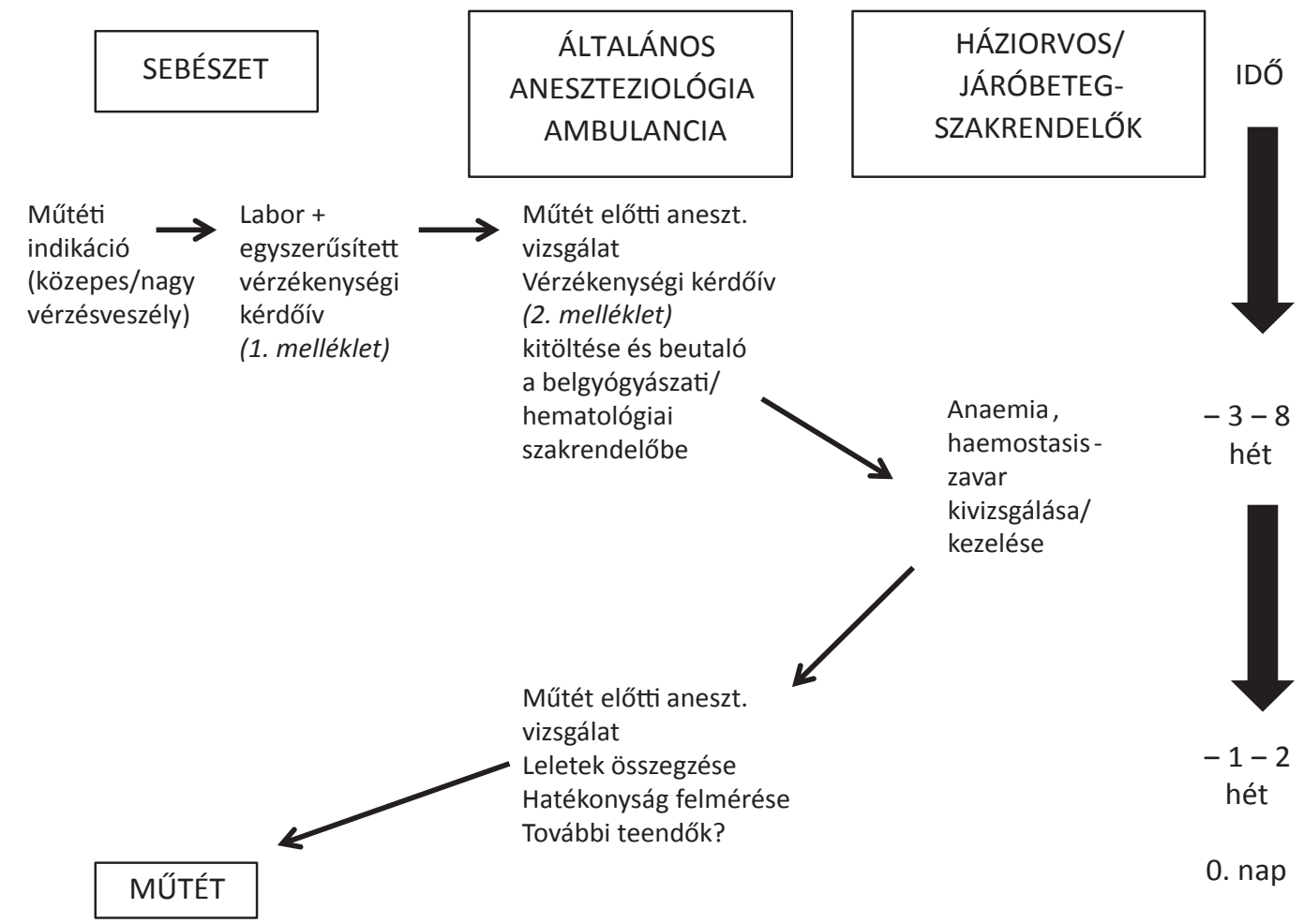

2/b. ábra Az anaemia preoperatív kivizsgálásának és kezelésének szervezése, a feladatok megosztása, ha perioperatív anaemia/haemostasis ambulancia nem áll rendelkezésre 
2. melléklet |A Nemzetközi Thrombosis és Haemostasis Társaság Vérzékenységi kérdőíve (ISTH-BAT) [36]

\begin{tabular}{|c|c|c|c|c|c|}
\hline & 0 pont & l pont & 2 pont & 3 pont & 4 pont \\
\hline Epistaxis & $\begin{array}{l}\text { Nincs/ } \\
\text { Jelentéktelen }\end{array}$ & $\begin{array}{l}>5 \text { alkalom/év vagy > } 10 \\
\text { perc időtartamú }\end{array}$ & $\begin{array}{l}\text { Csak orvosi vizsgálat } \\
\text { és konzultáció }\end{array}$ & $\begin{array}{l}\text { Tamponálás, kauterizá- } \\
\text { ció, antifibrinolitikum }\end{array}$ & $\begin{array}{l}\text { Transzfúzió vagy faktor- } \\
\text { pótlás vagy DDAVP }\end{array}$ \\
\hline $\begin{array}{l}\text { Bőrvérzés/ } \\
\text { Haematoma }\end{array}$ & $\begin{array}{l}\text { Nincs/ } \\
\text { Jelentéktelen }\end{array}$ & $\begin{array}{l}>5 \mathrm{db} 1 \mathrm{~cm} \text {-nél nagyobb } \\
\text { kiterjedésű bőrvérzés }\end{array}$ & $\begin{array}{l}\text { Csak orvosi vizsgálat } \\
\text { és konzultáció }\end{array}$ & Kiterjedt vérzés & $\begin{array}{l}\text { Transzfúziót igénylő } \\
\text { spontán kialakuló } \\
\text { haematoma }\end{array}$ \\
\hline $\begin{array}{l}\text { Kis sérülés } \\
\text { okozta vérzés }\end{array}$ & $\begin{array}{l}\text { Nincs/ } \\
\text { Jelentéktelen }\end{array}$ & $\begin{array}{l}>5 \text { alkalom/év vagy > } 10 \\
\text { perc időtartamú }\end{array}$ & $\begin{array}{l}\text { Csak orvosi vizsgálat } \\
\text { és konzultáció }\end{array}$ & $\begin{array}{l}\text { Sebészeti ellátás / } \\
\text { haemostasis }\end{array}$ & $\begin{array}{l}\text { Transzfúzió vagy faktor- } \\
\text { pótlás vagy DDAVP }\end{array}$ \\
\hline $\begin{array}{l}\text { Szájüregi } \\
\text { vérzés }\end{array}$ & $\begin{array}{l}\text { Nincs/ } \\
\text { Jelentéktelen }\end{array}$ & Előfordul(t) & $\begin{array}{l}\text { Csak orvosi vizsgálat } \\
\text { és konzultáció }\end{array}$ & $\begin{array}{l}\text { Sebészeti ellátás/ } \\
\text { haemostasis vagy } \\
\text { antifibrinolitikum }\end{array}$ & $\begin{array}{l}\text { Transzfúzió vagy faktor- } \\
\text { pótlás vagy DDAVP }\end{array}$ \\
\hline GI-vérzés & $\begin{array}{l}\text { Nincs/ } \\
\text { Jelentéktelen }\end{array}$ & $\begin{array}{l}\text { Elöfordult, de az ok NEM } \\
\text { fekély, portalis hyper- } \\
\text { tensio, nodus haemorrh. } \\
\text { vagy angiodysplasia }\end{array}$ & $\begin{array}{l}\text { Csak orvosi vizsgálat } \\
\text { és konzultáció }\end{array}$ & $\begin{array}{l}\text { Sebészeti ellátás/ } \\
\text { haemostasis vagy } \\
\text { antifibrinolitikum }\end{array}$ & $\begin{array}{l}\text { Transzfúzió vagy faktor- } \\
\text { pótlás vagy DDAVP }\end{array}$ \\
\hline Haematuria & $\begin{array}{l}\text { Nincs/ } \\
\text { Jelentéktelen }\end{array}$ & Makroszkópos & $\begin{array}{l}\text { Csak orvosi vizsgálat } \\
\text { és konzultáció }\end{array}$ & $\begin{array}{l}\text { Sebészeti ellátás, } \\
\text { vaspótlás }\end{array}$ & $\begin{array}{l}\text { Transzfúzió vagy faktor- } \\
\text { pótlás vagy DDAVP }\end{array}$ \\
\hline $\begin{array}{l}\text { Fogextractio } \\
\text { utáni vérzés }\end{array}$ & $\begin{array}{l}\text { Nincs/ } \\
\text { Jelentéktelen/ } \\
\text { Nem történt }\end{array}$ & $\begin{array}{l}\text { Az összes beavatkozás } \\
\leq 25 \% \text {-ában vérzés, nem } \\
\text { történt intervenció }\end{array}$ & $\begin{array}{l}\text { Az összes beavatkozás } \\
>25 \% \text {-ában vérzés, } \\
\text { nem történt interven- } \\
\text { ció }\end{array}$ & $\begin{array}{l}\text { Sutura/tartós } \\
\text { tamponálás }\end{array}$ & $\begin{array}{l}\text { Transzfúzió vagy faktor- } \\
\text { pótlás vagy DDAVP }\end{array}$ \\
\hline $\begin{array}{l}\text { Sebészeti } \\
\text { beavatkozás- } \\
\text { hoz társuló } \\
\text { vérzés }\end{array}$ & $\begin{array}{l}\text { Nincs/ } \\
\text { Jelentéktelen/ } \\
\text { Nem történt }\end{array}$ & $\begin{array}{l}\text { Az összes beavatkozás } \\
\leq 25 \% \text {-ában vérzés, nem } \\
\text { történt intervenció }\end{array}$ & $\begin{array}{l}\text { Az összes beavatkozás } \\
>25 \% \text {-ában vérzés, } \\
\text { nem történt interven- } \\
\text { ció }\end{array}$ & $\begin{array}{l}\text { Sebészi vérzéscsillapítás } \\
\text { vagy antifibrinolitikum }\end{array}$ & $\begin{array}{l}\text { Transzfúzió vagy faktor- } \\
\text { pótlás vagy DDAVP }\end{array}$ \\
\hline Menorrhagia & $\begin{array}{l}\text { Nincs/ } \\
\text { Jelentéktelen }\end{array}$ & $\begin{array}{l}\text { - Orvosi vizsgálat/ } \\
\text { konzultáció vagy } \\
\text { - Tamponcsere <2 } \\
\text { óránként vagy alvadék } \\
\text { és elárasztásszerú vérzés } \\
\text { vagy } \\
\text { - PBAC-score >100 }\end{array}$ & $\begin{array}{l}\text { - Hiányzás munká- } \\
\text { ból/iskolából >2 } \\
\text { alkalom/év vagy } \\
\text { - Antifibrinolitikum } \\
\text { vagy hormon- vagy } \\
\text { vaskezelés szükséges }\end{array}$ & $\begin{array}{l}\text { - Antifibrinolitikum és } \\
\text { hormonkezelés } \\
\text { kombinációja } \\
\text { szükséges vagy } \\
\text { - A menarche óta és } \\
\text { >12 hónapja fennáll }\end{array}$ & $\begin{array}{l}\text { - Kórházi felvételt vagy } \\
\text { sürgősségi ellátást } \\
\text { igénylő akut } \\
\text { menorrhagia vagy } \\
\text { - Transzfúzió vagy } \\
\text { faktorpótlás vagy } \\
\text { DDAVP szükséges } \\
\text { - Curettage vagy } \\
\text { endometriumablatio } \\
\text { vagy hysterectomia }\end{array}$ \\
\hline $\begin{array}{l}\text { Postpartum } \\
\text { vérzés }\end{array}$ & $\begin{array}{l}\text { Nincs/ } \\
\text { Jelentéktelen } \\
\text { Még nem szült }\end{array}$ & $\begin{array}{l}\text { - Orvosi konzultáció vagy } \\
\text { - Oxitocin használata } \\
\text { postpartum vérzés miatt } \\
\text { vagy } \\
\text { - Lochia >6 hét után }\end{array}$ & $\begin{array}{l}\text { - Vasterápia vagy } \\
\text { antifibrinolitikum } \\
\text { alkalmazása } \\
\text { postpartum vérzés } \\
\text { miatt }\end{array}$ & $\begin{array}{l}\text { - Transzfúzió vagy } \\
\text { faktorpótlás vagy } \\
\text { DDAVP szükséges } \\
\text { vagy } \\
\text { - Anesztézia mellett } \\
\text { vizsgálat és/vagy } \\
\text { uterusballon/ } \\
\text { tamponálás szükséges }\end{array}$ & $\begin{array}{l}\text { Sürgős sebészi } \\
\text { beavatkozás igénye } \\
\text { (hysterectomia, arteria } \\
\text { iliaca interna lekötés, } \\
\text { arteria uterina } \\
\text { embolisatio, uterus- } \\
\text { varratok) }\end{array}$ \\
\hline $\begin{array}{l}\text { Izomhaema- } \\
\text { toma }\end{array}$ & Soha & $\begin{array}{l}\text { Poszttraumás, nincs } \\
\text { kezelés }\end{array}$ & Spontán, nincs kezelés & $\begin{array}{l}\text { Spontán vagy traumás } \\
\text { + DDAVP- vagy } \\
\text { faktorpótló kezelés }\end{array}$ & $\begin{array}{l}\text { Spontán vagy traumás } \\
\text { + sebészeti ellátás vagy } \\
\text { transzfúzió }\end{array}$ \\
\hline $\begin{array}{l}\text { Haemar- } \\
\text { throsis }\end{array}$ & Soha & $\begin{array}{l}\text { Poszttraumás, nincs } \\
\text { kezelés }\end{array}$ & Spontán, nincs kezelés & $\begin{array}{l}\text { Spontán vagy traumás } \\
\text { + DDAVP- vagy } \\
\text { faktorpótló kezelés }\end{array}$ & $\begin{array}{l}\text { Spontán vagy traumás } \\
\text { + sebészeti ellátás vagy } \\
\text { transzfúzió }\end{array}$ \\
\hline KIR-vérzés & Soha & - & - & $\begin{array}{l}\text { Subduralis + bármilyen } \\
\text { beavatkozás }\end{array}$ & $\begin{array}{l}\text { Intracerebrális }+ \\
\text { bármilyen beavatkozás }\end{array}$ \\
\hline Egyéb vérzés & $\begin{array}{l}\text { Nincs/ } \\
\text { Jelentéktelen }\end{array}$ & Előfordul(t) & $\begin{array}{l}\text { Csak orvosi vizsgálat } \\
\text { és konzultáció }\end{array}$ & $\begin{array}{l}\text { Sebészeti ellátás/ } \\
\text { haemostasis vagy } \\
\text { antifibrinolitikum }\end{array}$ & $\begin{array}{l}\text { Transzfúzió vagy faktor- } \\
\text { pótlás vagy DDAVP }\end{array}$ \\
\hline
\end{tabular}

https://cdn.ymaws.com/www.isth.org/resource/resmgr/ssc/isth-ssc_bleeding_assessment.pdf 
2. melléklet folyt.

Az ISTH-BAT értékelése:

- Minden vérzéstípusnál a legsúlyosabb megnyilvánulási formát kell figyelembe venni

- A különböző vérzéstípusokra kapott pontszámot összesíteni kell. További vérzékenységirányú kivizsgálás javasolt, ha az összpontszám:

o nőknél $>5$ pont,

o férfiaknál >3 pont,

o gyermekeknél $>2$ pont.

- Az ISTH-BAT-vizsgálatot minden esetben ki kell egészíteni a családi anamnézissel és a beteg által szedett, a haemostasisrendszer múködését befolyásoló gyógyszerek és társbetegségek dokumentálásával:

o további kivizsgálás javasolt, ha a családi anamnézis pozitív örökletes, vérzékenységet okozó betegség tekintetében, vagy valószínúsíthető, hogy a családban ilyen betegség előfordult, de még nem vizsgálták ki, vagy nem született definitív diagnózis;

o amennyiben a beteg a haemostasisrendszer múködésére ható gyógyszert szed, az érvényes ajánlások figyelembevételével kell a mútét előtt eljárni a gyógyszer kihagyását, felfüggesztését illetően

DDAVP = dezmopresszin; GI = gastrointestinalis; KIR = központi idegrendszer; PBAC = menstruációs vérzési napló

séges lehet (lásd alább). A Magyar Thrombosis és Haemostasis Társaság a fenti megállapításokkal egyetért, de a mútétek előtt végzett alvadási szűrőtesztek liberálisabb alkalmazását sem tekinti hibának, és támogatja azt.

- Ha az anamnézis és a haemostasis-kérdőívek eredménye alapján felmerül a vérzékenység gyanúja, részletes haemostaseologiai kivizsgálás és szükség esetén kezelés szükséges a témában jártas hematológus bevonásával.

- Az alap-haemostasisparaméterek (APTI, PI, TI) és a thrombocytaszám rutinszerú vizsgálatának megfontolása javasolt a következő betegcsoportoknál:

o az egyén életében az első, szignifikáns vérzés veszélyével járó invazív/mútéti beavatkozás előtt, o neuraxiális anesztézia/analgesia alkalmazása előtt, o vérzéssel járó szemészeti, idegsebészeti beavatkozás, elsősorban craniectomia előtt,

o igen nagy vérzésveszéllyel járó beavatkozások előtt.

- A thrombocytafunkció perioperatív vizsgálata rutinszerüen nem ajánlott $(2 \mathrm{~B})$.

- A thrombocytafunkció perioperatív vizsgálata segítheti a klinikai döntéshozatalt thrombocytaaggregáció-gátló kezelés esetén (2B).

- A vérzési időt számos tényező befolyásolja, nem alkalmas a vérzési kockázat megítélésére, használata nem javasolt (1C).

- Elektív mútétek előtt a haemostasisrendszer múködésére ható gyógyszereket az aktuális ajánlások ismeretében kell kihagyni [37].

- Friss fagyasztott plazma (FFP) alkalmazása PI/INR korrekcióra a preoperatív szakban nem ajánlott (IC).

- A FFP önmagában nem alkalmas a hypofibrinogenaemia korrekciójára (1C).

\section{A iatrogén vérvesztés mérséklése}

A laboratóriumi vizsgálatok céljából végzett, nem megfelelően tervezett és sokszor indokolatlan vérvételek iatrogén anaemiát okozhatnak, amely negatív hatással lehet a kórlefolyásra. Racionalizálni és minimalizálni kell ezért a diagnosztikai célból levett vérmennyiséget [38]:

- Gyerek laboratóriumi vizsgálati csövek alkalmazása javasolt; a vérvételi csöveket kisebb mennyiségű vérrel töltsük meg, ha az nem befolyásolja a diagnosztikus tesztek értékelhetőségét; fontos a különböző laboratóriumi alegységek múködésének összehangolása, tehát egy mintából többféle vizsgálat végzése.

- A vérvételek racionalizálása, összehangolása és individualizálása a rutinszerüen végzett panelvizsgálatok helyett.

- Megfelelő indikáció esetén a point-of-care (POC-) tesztek alkalmazásának megfontolása, melyek az alvadás dinamikus monitorozását teszik lehetővé kis mennyiségú vér felhasználásával.

- Anaemia és/vagy magas vérzési kockázat esetén zárt öblítőrendszerek alkalmazása ajánlott artériás és centrális vénás katéterek használatakor.

\section{Az intraoperativ vérvesztés mérséklése}

\section{Sebészeti haemostasis/megengedő hypotensio}

Az életet közvetlenül veszélyeztető sokkos állapot kialakulásához lumenes sebészi és szekunder coagulopathia következtében kialakuló diffúz vérzés egyaránt hozzájárulhat. A perioperatív vérzés csökkentése interdiszciplináris megközelítést igényel, melynek alapvető elemei a gondos sebészi vérzéscsillapítás, a homeostasis, valamint a haemostasis élettani múködésének fenntartása a stabil faktorkoncentrátumok allogén vérkészítményekkel szembeni preferálása mellett.

A vér- és volumenvesztés minimalizálásához elengedhetetlen a haemorrhagia fó forrásaként szolgáló lumenes vérzés mihamarabbi sebészi ellátása, illetve a mútét során mindvégig alkalmazott atraumatikus sebészi technika és gondos vérzéscsillapítás, mely magában foglalja a lokális 
hemosztriptikumok szükség szerinti alkalmazását is. Előnyben részesítendők a minimálinvazív eljárások. A sokkos állapot megelőzése és a megfelelő szöveti perfúzió biztosítása krisztalloid \pm kolloid oldatok infúzióját teszi szükségessé, amely egyéb tényezők (consumptio, alvadási faktorok vesztése stb.) mellett dilutiós, szekunder coagulopathiához vezethet. Ezért, ha nem ellenjavallt, restriktív volumenpótlás és permisszív hypotensio (artériás középnyomás $\geq 60 \mathrm{Hgmm}$, szisztolés artériás nyomás $\geq 80 \mathrm{Hgmm}$ ) alkalmazandó átmenetileg, a sebészeti vérzéscsillapítás megvalósulásáig.

\section{Vérmentö módszerek alkalmazása}

Vérmentő módszerek, 'cell saver' használata javasolt a nagy vérveszteséggel járó mütétek esetén (elsősorban szívsebészet, ortopédia, májtranszplantáció, aortaaneurysma-mútétek stb.) kontraindikáció hiányában. Leukocytadepletáló filterek alkalmazása növelheti a betegbiztonságot, és szélesítheti az indikációs kört.

\section{Optimális fiziológiás körülmények fenntartása}

- Sav-bázis háztartás: Az acidosis hátráltatja a trombinképződést és a primer haemostasist a thrombocytaadhézió és -aggregáció gátlásával. Az acidosis miatt a keletkező alvadék instabil lesz. Törekedni kell tehát a sav-bázis háztartás egyensúlyának biztosítására [39].

- Testhőmérséklet: A maghőmérséklet $35^{\circ} \mathrm{C}$ alá csökkenése szintén befolyásolja a plazma koagulációs po-

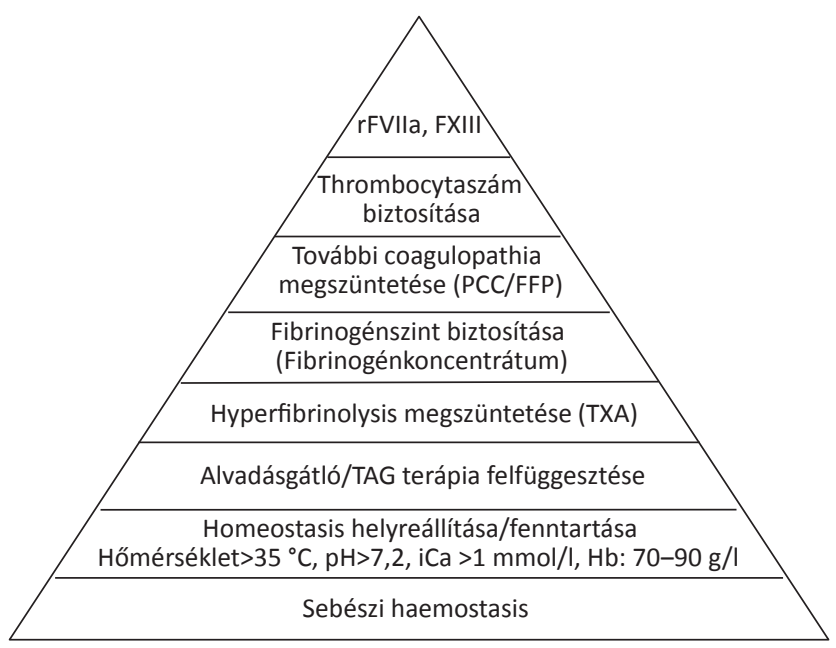

3. ábra

Intervenciós piramis masszív vérzéshez társuló szekunder coa gulopathia kezeléséhez (Görlinger után [41]). A beavatkozások sorrendje a piramis aljától indulva és felfelé haladva a megfelelő en múködő haemostasisrendszer biztosítása érdekében, ideális esetben viszkoelasztikus teszttel történő monitorozás mellett

FFP = friss fagyasztott plazma; FXIII = a XIII-as számú véralvadási faktor; $\mathrm{Hb}=$ hemoglobin; $\mathrm{iCa}=$ ionizált kalcium; $\mathrm{PCC}=$ protrombinkomplex-koncentrátum; rFVIIa $=$ a VII-es számú rekombináns aktivált alvadási faktor; TAG $=$ thrombocytaaggregáció-gátló; TXA = tranexámsav tenciálját és a primer haemostasist is; alacsony testhőmérséklet esetén az alvadék később és lassabban képződik. A haemostasis megfelelő múködéséhez fontos tehát a normothermia fenntartása a passzív és aktív melegítés módszereinek alkalmazásával [39].

- Kalcium: Az ionizált kalcium (iCa) - számos egyéb élettani funkciója mellett - nélkülözhetetlen bizonyos prokoaguláns faktorok (II., VII., IX., X.) aktivációjához és múködéséhez is. Az iCa mennyisége fordítottan arányos a szérumlaktáttal, metabolikus acidosisban ezért jelentős hypocalcaemia alakulhat ki. A kalcium kötődhet az allogén vérkészítményekben található citráthoz is. A masszív vérzést és transzfúziót kísérő hypocalcaemia azonnali kezelésre szorul, a szérum-iCa-koncentráció célértéke >1 mmol/l.

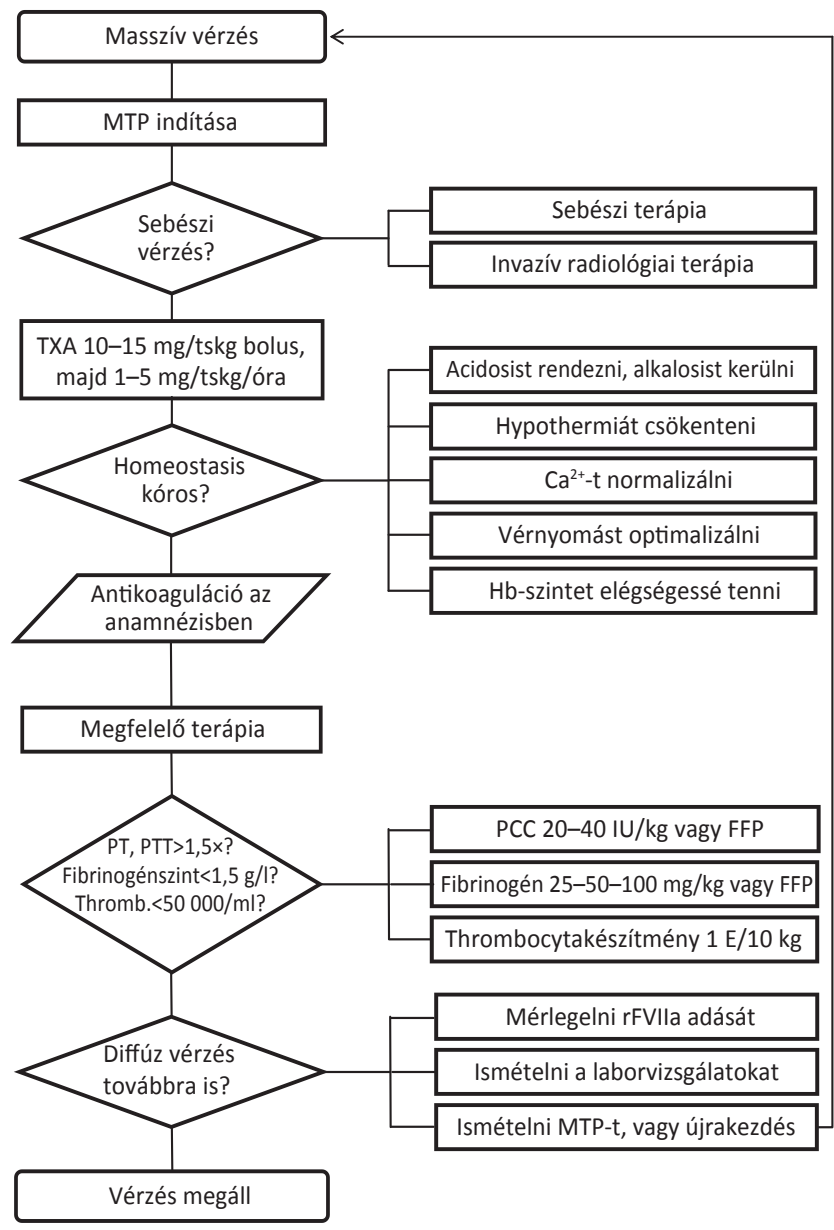

\begin{tabular}{l|l} 
4/a ábra & Masszív vérzések ellátása viszkoelasztikus teszt hiányában
\end{tabular} $\mathrm{Ca}=$ kalcium $; \mathrm{FFP}$ = friss fagyasztott plazma $\mathrm{Hb}=$ hemoglobin; MTP $=$ masszív transzfúziós protokoll $;$ PCC $=$ protrombin komplex-koncentrátum; PT = protrombinidó; PTT = parciális tromboplasztinidó; rFVIIa = a VII-es számú rekombináns aktivált alvadási faktor; Thromb. $=$ thrombocyta; $\mathrm{TXA}=$ tranexámsav

Forrás: Az életveszélyes perioperatív vérzések ellátása: A Magyar Aneszteziológiai és Intenzív Terápiás Társaság szakmai irányelve 2013; 43: 113-143. 


\section{A masszív vérzés ellátásával kapcsolatos protokoll alkalmazása}

Az akut masszív vérzés kezelésének multidiszciplináris megközelítése intézményenként megfelelő, a nemzetközi ajánlásokat tartalmazó protokoll kidolgozását és alkalmazását teszi szükségessé, mely azonban figyelembe veszi a helyi viszonyokat, és alkalmazkodik a helyi sajátosságokhoz is. Ezek folyamatos, rendszeres revideálása és kiegészítése szükséges a legújabb szakmai irányelveknek megfelelően [31, 35].

A masszív vérzés hatékony kezelése és a vérveszteség minimalizálása érdekében célvezérelt, faktorkoncentrátum-alapú terápia alkalmazása javasolt az intervenciós piramis alkalmazásával (3. ábra), viszkoelasztikus POCeszközökkel történő monitorozás mellett $[40,41]$. Ez a fajta megközelítés igyekszik a masszív transzfúziót elkerülni, illetve megelőzni. A hagyományos értelemben vett masszív transzfúziós protokollok alkalmazása tehát - amelyek előre meghatározottan, fix arányban alkalmaznak allogén vérkészítményeket (VVS : FFP : THR) visszaszorulóban van, elsősorban a POC-eszközök hiányában lehet még létjogosultságuk, bár a FFP helyett és/ vagy mellett már ezekben az esetekben is a faktorkoncentrátumok használata kerül előtérbe. A cél azonban egyértelmúen a masszív transzfúziók megelőzése a korai célvezérelt kezelés széles körú használatával. Masszív vérzések kezelésekor a Magyar Aneszteziológiai Társaság Szakmai Kollégiumának (MAITSZK) ajánlása az irányadó, melynek frissítése a közeljövőben esedékes (4/a és 4/b ábra) [35]. A masszív vérzések modern ellátásához szükséges faktorkészítmények (elsősorban fibrinogén, protrombinkomplex-koncentrátum [PCC], FXIII.) a megfelelő mennyiségben, a nap 24 órájában rendelkezésre kell, hogy álljanak.

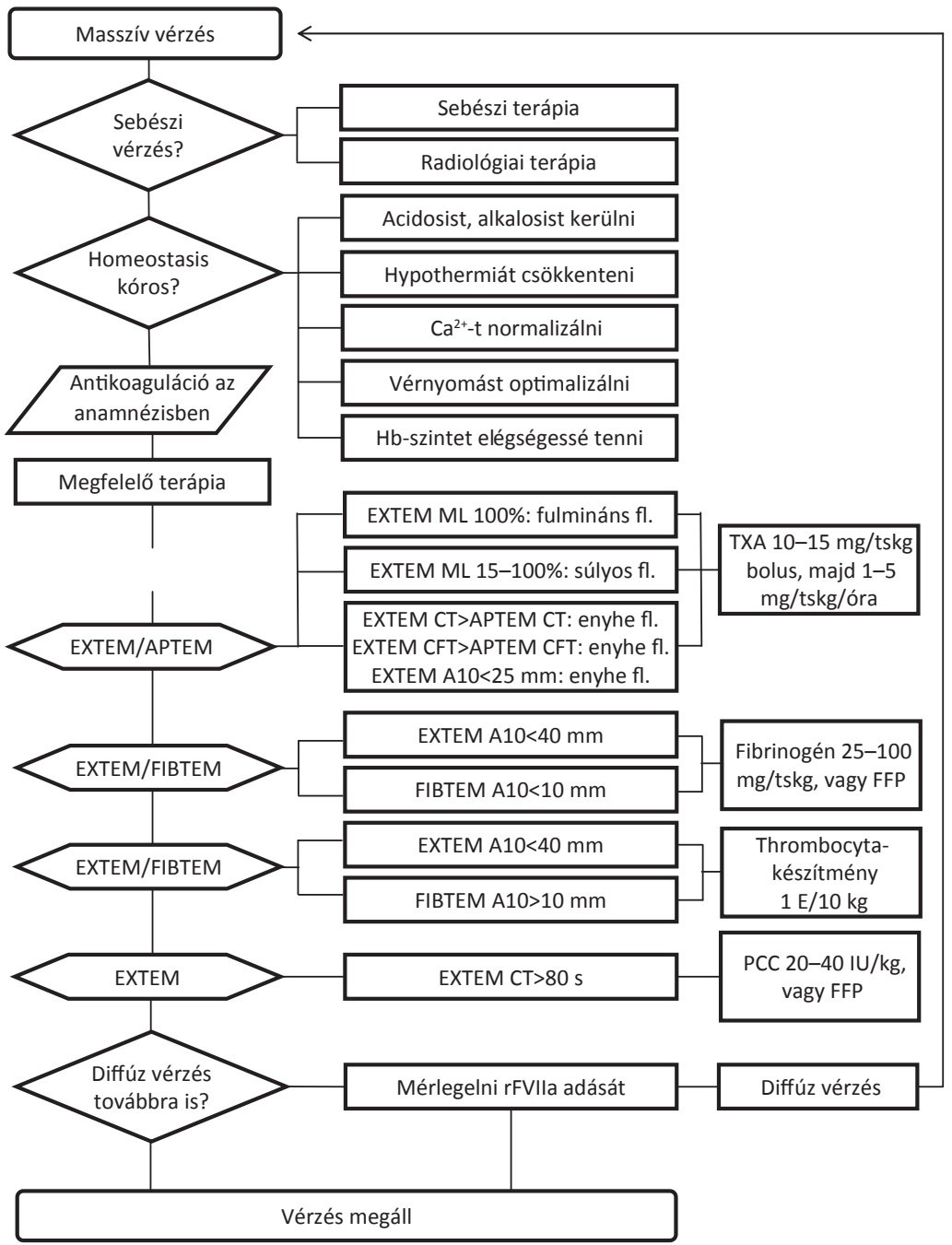

4/b ábra

Masszív vérzések ellátása viszkoelasztikus teszttel történő monitorozás során

$\mathrm{A}=$ amplitudó; $\mathrm{Ca}=$ kalcium; $\mathrm{CFT}=$ alvadékképződési idő; $\mathrm{CT}=$ alvadási idő; $\mathrm{FFP}=$ friss fagyasztott plazma; fl. = fibrinolysis; $\mathrm{Hb}=$ hemoglobin; $\mathrm{ML}=$ maximális lysis; $\mathrm{PCC}=$ protrombinkomplex-koncentrátum; $\mathrm{rFVIIa}=\mathrm{a}$ VII-es számú rekombináns aktivált alvadási faktor; $\mathrm{TXA}=$ tranexámsav

Forrás: Az életveszélyes perioperatív vérzések ellátása: A Magyar Aneszteziológiai és Intenzív Terápiás Társaság szakmai irányelve 2013; 43: 113-143. 


\section{Harmadik pillér: az anaemiával szembeni tolevancia fokozása, az oxigén kinálat- keveslet megfelelö arányának biztositása}

Az oxigénkínálat és -kereslet megfeleló arányának biztosítása segíti az anaemiával szembeni tolerancia növelését, ezért a teljes perioperatív időszakban javasoltak a következők:

- A kívánatos oxigénkínálat fenntartása a megfeleló perctérfogat, perfúziós nyomás, oxigénszállító kapacitás és oxigenizáció biztosításával.

- Az élettani tartalékok és rizikótényezők egyéni felmérése, rendezése, a társbetegségek megfelelő kezelése. A beteg a rendelkezésre álló idő alatt elérhetô legjobb általános állapotban kerüljön a mútőbe. Ennek érdekében individualizált kezelési terv elózetes készítése, majd alkalmazása és rendszeres revideálása szükséges.

- A hemodinamikai stabilitás és normovolaemia biztosítása a teljes perioperatív szakban; ehhez élni kell a korszerü hemodinamikai monitorozás lehetőségeivel.

- Az oxigénigény csökkentése: többek között a megfelelően megválasztott és kivitelezett anesztézia a kellőképpen mély narkózis, fájdalomcsillapítás, légzéstámogatás, lázcsillapítás és szükség szerinti izomrelaxáció biztosításával.

- Masszív vérzés esetén az artériás vérben az oxigén 200 Hgmm parciális nyomásértékig emelhetó, ennél magasabb érték, extrém hyperoxia nem javasolt [31, 35].

- A cardialis állapot, a szív tartalékainak, terhelhetőségének és alkalmazkodóképességének feltérképezése ajánlott magas vérzési kockázatú mútéti beavatkozások előtt.

\section{A vérkészítmények észszerü és indokolt alkalmazásának támogatása mellett az irracionális transzfúziós gyakorlat megszüntetése}

\section{Restriktí transzfúziós gyakorlat alkalmazása}

Az Európai Aneszteziológiai Társaság és a MAITSZK ajánlásainak ismeretében kijelenthető, hogy egyénre szabott restriktív transzfúziós stratégia alkalmazása javasolt, mely csökkenti a betegek expozícióját az allogén vérkészítményekkel szemben (1A), és ezáltal mérsékli a transzfúziós reakciók és a transzfúzióval kapcsolatos szövődmények számát.

A PBM keretein belül, vérigénylés előtt ellenőrző kérdőív (3. melléklet) [42] használata javasolt, amely segít elkerülni a vérkészítmények szükségtelen rendelését és felhasználását.

A vérkészítmények racionalizált alkalmazása elengedhetetlen a perioperatív ellátás minőségének javításához.

A Hb-érték egyedüli, önálló transzfúziós triggeri szerepe vitatott.
Az Országos Vérellátó Szolgálat Transzfúziós Szabályzata (OVSZ 2014) szerint és azzal egyetértésben:

- VVS-készítmények alkalmazása a szöveti oxigénkínálat, illetve oxigéntranszport javítása érdekében történhet.

- A VVS-transzfúzió szükségességét nem lehet kizárólag a beteg hemoglobin- vagy hematokritértékéhez kötni. Az indikáció felállításakor az anaemia klinikai jelei, a beteg aktuális klinikai állapota, a szöveti oxigenizáció, az alap- és társbetegségek és a vérveszteség mértéke együtt értékelendő.

- Akut vérveszteség esetén a teljes vértérfogat 30\%ának elvesztése a VVS-szubsztitúció relatív indikációja; a teljes vértérfogat 40\%-ának elvesztésekor krisztalloid és kolloid adása mellett a VVS-eket is pótolni kell.

- Általános érvényú szabály nincs, de ha a hemoglobinszint $60 \mathrm{~g} / \mathrm{l}$ alá csökken, szinte mindig, ha pedig 100 $\mathrm{g} / \mathrm{l}$ felett van, akkor nagyon ritkán indokolt a VVStranszfúzió [43].

- Krónikus, terápiarezisztens, normovolaemiás anaemia esetén a legtöbb betegnél $70 \mathrm{~g} / \mathrm{l}$ alatti hemoglobinértéknél jelentkeznek az anaemia tünetei, transzfúzió általában csak ezen érték alatt indokolt. Szív- vagy tüdőbetegségben szenvedőknél, a központi idegrendszer sérülésekor és egyénre szabottan, a klinikai képtől függően a hemoglobin-küszöbérték (a tünetektől függően) magasabb lehet.

- VVS-készítményeket kontraindikált alkalmazni, amíg a megfelelő szöveti perfúzió és oxigénkínálat biztosítható krisztalloid vagy kolloid oldatok adása mellett.

- VVS-készítményeket általában és relatíve kontraindikált alkalmazni a krónikus anaemia olyan eseteiben, amikor az más, gyógyszeres úton kezelhető (például vas, $B_{12}$-vitamin, folsav, eritropoetin).

3. melléklet |Ellenőrző lista transzfúzió/vérrendelés előtt (Frankfurt Univer sity Hospital) [42]

\section{ELLENŐRZŐ LISTA TRANSZFÚZIÓ/VÉRRENDELÉS ELŐTT}

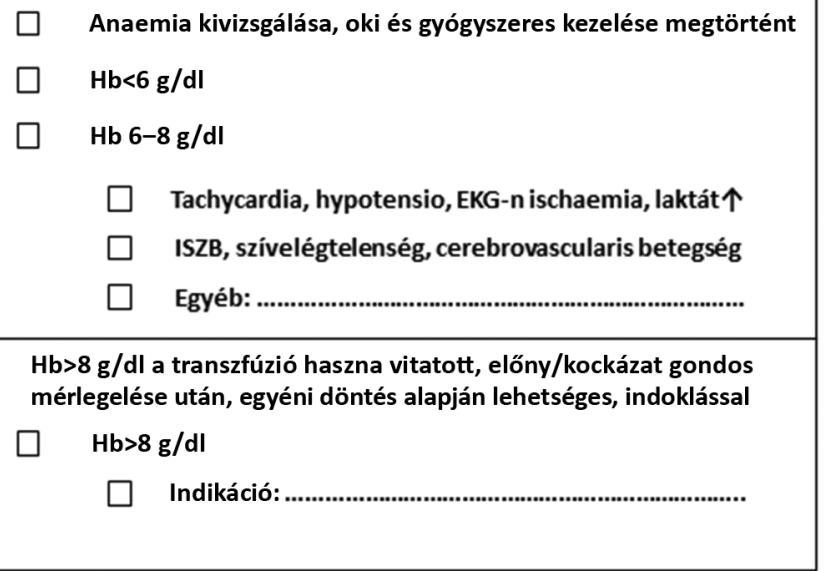

$\mathrm{Hb}=$ hemoglobin; ISZB = ischaemiás szívbetegség 


\section{A várható vérvesztés/tolerálható vérvesztés becslése}

Magas vérzési kockázattal járó beavatkozás előtt célszerü megbecsülni a beteg által még tolerálható vérvesztés mennyiségét, amiben az alábbi képlet nyújt segítséget:

Tolerált vérveszteség $=\mathrm{VV} \times\left(\mathrm{HTC}_{\text {preop }}-\mathrm{HTC}_{\min }\right) \times$ 0,91 ,

ahol a VV a vérvolumen, a $\mathrm{HTC}_{\text {preop }}$ a preoperatív, a $\mathrm{HTC}_{\text {min }}$ pedig a beteg által még tolerálható hematokritérték.

A minimális (még megengedett) hematokritérték meghatározását minden egyes betegnél egyénre szabottan kell elvégezni [44].

A beavatkozásokhoz az alábbi egyenlet alapján becsült vérmennyiség tartalékolása, rendelkezésre állása szükséges:

Szükséges vérmennyiség $=$ várható vérveszteség $-\mathrm{VV}$ $\times\left(\mathrm{HTC}_{\text {preop }}-\mathrm{HTC}_{\mathrm{min}}\right) \times 0,91$.

\section{Külön központi egység müködtetése a vérkészitmények racionális, szervezett elosztásához, felhasználásához}

A nagy betegszámmal és transzfúziós igénnyel rendelkező fekvőbeteg-intézményekben a vérkészítmények gazdaságos, összehangolt, hatékony és észszerú felhasználása, valamint biztonságos és szakszerü tárolása érdekében külön erre a célra létrehozott központi egység (vérdepó) múködtetése javasolt a nap 24 órájában.

Magyarországon a PBM rendszerszintű alkalmazása még nem terjedt el. Mihamarabbi bevezetése és megvalósítása a betegbiztonság növelése és a hatékony nemzeti vérgazdálkodás érdekében elengedhetetlen. A fentiekben vázolt koncepciót - a Nemzeti Véradó és Vérmentő Programot - a PBM magyar viszonyokhoz adaptált szakmai ajánlásának, az irányelvek bemutatkozó vitaanyagának szánjuk. Bízunk abban, hogy alkalmazásával és további finomhangolásával Magyarországon is jelentős előrelépés érhető el az irracionális transzfúziós gyakorlat megszüntetése, a vértakarékosság és a betegbiztonság területén.

Anyagi támogatás: A közlemény megírása anyagi támogatásban nem részesült.

Szerzői munkamegosztás: O. Zs., F. B., G. J., M. A. és B. B. a kézirat és az ábrák elkészítésében, az irodalomgyưjtésben és az egyes fejezetek elkészítésében egyaránt részt vett. A kézirat végleges változatát valamennyi szerző elolvasta és jóváhagyta.

Érdekeltségek: A szerzőknek a kézirat elkészítésével kapcsolatban nincsenek érdekeltségeik.

\section{Irodalom}

[1] European Commission Directorate-General for Health and Food Safety. Summary of the 2016 annual reporting of serious adverse reactions and events for blood and blood components. Available from: https://ec.europa.eu/health/sites/health/ files/blood_tissues_organs/docs/2016_sare_blood_summary_ en.pdf [accessed: March 8, 2020].

[2] World Health Organization. Global Forum for Blood Safety: Patient Blood Management. Available from: https://www.who. int/bloodsafety/events/gfbs_01_pbm_concept_paper.pdf [accessed: March 8, 2020].

[3] Isbister JP. The paradigm shift in blood transfusion. Med J Aus. 1988; 148: 306-308.

[4] Meybohm P, Herrmann E, Steinbicker AU, et al. Patient Blood Management is associated with a substantial reduction of red blood cell utilization and safe for patient's outcome: a prospective, multicenter cohort study with a noninferiority design. Ann Surg. 2016; 264: 203-211.

[5] Consensus/Action plan, lst Central Eastern Europe: Patient Blood Management Meeting (Budapest 01. 02. 2019). Available from: http://newsletter.esahq.org/lst-central-eastern-europepatient-blood-management-meeting-budapest-01-02-2019/ [accessed: 2020 March 8].

[6] Retteghy TA. Perioperative patient blood management. [Vértakarékos betegellátás a perioperatív szakban.] Hematol Transzfuz. 2018; 51: 194-203. [Hungarian]

[7] Babik B, Fazakas J, Matusovits A, et al. Forced steps for making improvements in severe perioperative haemorrhage. [Lépéskényszerben - új feladatok az életveszélyes perioperatív vérzések ellátásában.] Orv Hetil. 2019; 160: 203-213. [Hungarian]

[8] Baron DM, Hochrieser H, Posch M, et al. Preoperative anaemia is associated with poor clinical outcome in non-cardiac surgery patients. Br J Anaesth. 2014; 113: 416-423.

[9] Musallam KM, Tamim HM, Richards T, et al. Preoperative anaemia and postoperative outcomes in non-cardiac surgery: a retrospective cohort study. Lancet 2011; 378: 1396-1407.

[10] Nemergut EC, Littlewood KE, de Souza DG. Perioperative hematocrit levels and outcomes after non-cardiac surgery. JAMA 2007; 298: 1512-1514.

[11] Walsh M, Garg AX, Devereaux PJ, et al. The association between perioperative hemoglobin and acute kidney injury in patients having noncardiac surgery. Anesth Analg. 2013; 117: 924-931.

[12] Hogervorst E, Rosseel P, van der Bom J, et al. Tolerance of intraoperative hemoglobin decrease during cardiac surgery. Transfusion 2014; 54: 2692-2704.

[13] Petrou A, Tzimas P, Siminelakis S. Massive bleeding in cardiac surgery. Definitions, predictors and challenges. Hippokratia 2016; 20: 179-186.

[14] Thiele RH, Raphael J. A 2014 update on coagulation management for cardiopulmonary bypass. Semin Cardiothorac Vasc Anesth. 2014; 18: 177-189.

[15] Karkouti K, Callum J, Wijeysundera DN, et al. Point-of-care hemostatic testing in cardiac surgery: a stepped-wedge clustered randomized controlled trial. Circulation 2016; 134: 1152-1162.

[16] Curry N, Hopewell S, Dorée C, et al. The acute management of trauma hemorrhage: a systematic review of randomized controlled trials. Crit Care 2011; 15: R92.

[17] Knapp J, Hofer S, Lier H. Anesthesiological approach to postpartum hemorrhage. [Anästhesiologisches Vorgehen bei peripartaler Blutung.] Anaesthesist 2016; 65: 225-240. [German]

[18] Joseph KS, Rouleau J, Kramer MS, et al. Investigation of an increase in postpartum haemorrhage in Canada. BJOG 2007; 114: 751-759.

[19] Refaai MA, Blumberg N. The transfusion dilemma - weighing the known and newly proposed risks of blood transfusions 
against the uncertain benefits. Best Pract Res Clin Anaesthesiol. $2013 ; 27: 17-35$.

[20] Napolitano LM, Kurek S, Luchette FA, et al. Clinical practice guideline: red blood cell transfusion in adult trauma and critical care. J Trauma 2009; 67: 1439-1442.

[21] Rohde JM, Dimcheff DE, Blumberg N, et al. Health care-asssociated infection after red blood cell transfusion: a systematic review and meta-analysis. JAMA 2014; 311: 1317-1326. [Correction: JAMA 2014; 312: 2045.]

[22] Isil CT, Yazici P, Bakir I. Risk factors and outcome of increased red blood cell transfusion in cardiac surgical patients aged 65 years and older. Thorac Cardiovasc Surg. 2015; 63: 39-44.

[23] Carson JL. Blood transfusion and risk of infection: new convincing evidence. JAMA 2014; 311: 1293-1294.

[24] Vörös K. Patient safety in clinical transfusion practice. [Betegbiztonság a klinikai transzfuziológiában.] Hematol Transzfuz. 2019; 52: 169-176. [Hungarian]

[25] Theusinger OM, Kind SL, Seifert B, et al. Patient blood management in orthopaedic surgery: a four year follow-up of transfusion requirements and blood loss from 2008 to 2011 at the Balgrist University Hospital in Zurich, Switzerland. Blood Transfus. 2014; 12: 195-203.

[26] Goodnough LT, Shieh L, Hadhazy E, et al. Improved blood utilization using real-time clinical decision support. Transfusion 2014; 54: 1358-1365.

[27] Gross I, Seifert B, Hofmann A, et al. Patient blood management in cardiac surgery results in fewer transfusions and better outcome. Transfusion 2015; 55: 1075-1081.

[28] Trentino KM, Farmer SL, Swain SG, et al. Increased hospital costs associated with red blood cell transfusion. Transfusion 2015; 55: 1082-1089.

[29] Farmer SL, Trentino K, Hofmann A, et al. A pragmatic approach to Patient Blood Management - reducing transfusions and improving patient outcomes. Open Anesthesiol J. 2015; 9: 6-16.

[30] European Commission Directorate-General for Health and Food Safety. Supporting Patient Blood Management (PBM) in the EU. A practical implementation guide for hospitals. Available from: https://ec.europa.eu/health/sites/health/files/blood_ tissues_organs/docs/2017_eupbm_hospitals_en.pdf [accessed: March 8, 2020].

[31] Kozek-Langenecker SA, Ahmed AB, Afshari A, et al. Management of severe perioperative bleeding: guidelines from the European Society of Anesthesiology: first update 2016. Eur J Anaesthesiol. 2017; 34: 332-395.

[32] Ganzoni AM. Intravenous iron-dextran: therapeutic and experimental possibilities. [Eisen-Dextran intravenös: therapeutische und experimentelle Möglichkeiten.] Schweiz Med Wochenschr. 1970; 100: 301-303. [German]
[33] Muñoz M, Gómez-Ramírez S, Kozek-Langeneker S, et al. 'Fit to fly': overcoming barriers to preoperative haemoglobin optimization in surgical patients. Br J Anaesth. 2015; 115: 15-24.

[34] Muñoz M, Acheson AG, Auerbach M, et al. International consensus statement on the perioperative management of anaemia and iron deficiency. Anaesthesia 2017; 72: 233-247.

[35] Babik B, Blaskó Gy, Fazakas J, et al. Management of life-threatening perioperative haemorrhages. [Az életveszélyes perioperatív vérzések ellátása. A Magyar Aneszteziológiai és Intenzív Terápiás Társaság szakmai irányelve, 2013.] Aneszteziol Int Ter. 2013; 43: 113-143.] [Hungarian]

[36] Rodeghiero F, Tosetto A, Abshire T, et al., on behalf of the ISTH/SSC Joint VWF and Perinatal/Pediatric Hemostasis Subcommittees Working Group. ISTH/SSC bleeding assessment tool: a standardized questionnaire and a proposal for a new bleeding score for inherited bleeding disorders. J Thromb Haemost. 2010; 8: 2063-2065.

[37] Tafur A, Douketis J. Perioperative management of anticoagulant and antiplatelet therapy. Heart 2018; 104: 1461-1467.

[38] Fowler RA, Berenson M. Blood conservation in the intensice care unit. Crit Care Med. 2003; 31(12 Suppl): S715-S720.

[39] Thorsen K, Ringdal KG, Strand K, et al. Clinical and cellular effects of hypothermia, acidosis and coagulopathy in major injury. Br J Surg. 2011; 98: 894-907.

[40] Görlinger K, Pérez-Ferrer A, Dirkmann D, et al. The role of evidence-based algorithms for rotational thromboelastometryguided bleeding management. Korean J Anesthesiol. 2019; 72: 297-322.

[41] Görlinger K, Dirkmann D, Hanke AA, et al. First-line therapy with coagulation factor concentrates combined with point-ofcare coagulation testing is associated with decreased allogeneic blood transfusion in cardiovascular surgery: a retrospective, single-center cohort study. Anesthesiology 2011; 115: 1179-1191.

[42] Meybohm P, Fischer DP, Geisen C, et al. Safety and effectiveness of a Patient Blood Management (PBM) program in surgical patients - the study design for a multi-centre prospective epidemiologic non-inferiority trial. BMC Health Serv Res. 2014; 14: 576.

[43] Carson JL, Stanworth SJ, Roubinian N, et al. Transfusion thresholds and other strategies for guiding allogeneic red blood cell transfusion. Cochrane Database Syst Rev. 2016; 10: CD002042.

[44] Inghilleri G. Prediction of transfusion requirements in surgical patients: a review. Transf Alternat Transf Med. 2010; 11: 10-19.

(Oláh Zsolt dr., Debrecen, Nagyerdei krt. 98., 4032 e-mail: zsolah@med.unideb.hu)

A cikk a Creative Commons Attribution 4.0 International License (https://creativecommons.org/licenses/by/4.0/) feltételei szerint publikált Open Access közlemény, melynek szellemében a cikk bármilyen médiumban szabadon felhasználható, megosztható és újraközölhető, feltéve, hogy az eredeti szerző és a közlés helye, illetve a CC License linkje és az esetlegesen végrehajtott módosítások feltüntetésre kerülnek. (SID_1) 